\title{
FISHING, PROCESSING, COMMERCIALIZATION AND A PROPOSE TO FISHERY WASTE REUSE OF SURURU Mytella falcata IN THE MUNDAÚ LAGOON, MACEIÓ - AL, BRAZIL
}

Universidade de São Paulona Tieko Omena Tamano luanatamano@yahoo.com.br

Beethoven Brandão Correia de Lima Instituto Federal de Alagoas, Campus Maceió, Maceió, AL, Brasil zeitgeist-2009@hotmail.com

Joseane da Silva

Universidade Estadual Paulista, Centro de Aquicultura da UNESP, Jaboticabal, SP, Brasil biologiajoseane@gmail.com

Daniel de Magalhães Araujo Instituto Federal de Alagoas, Programa de Pós-Graduação em Tecnologias Ambientais, Satuba, AL, Brasil daniel.araujo@ifal.edu.br

\begin{abstract}
A diagnosis was made on the fishing, processing, commercialization and generation of residues of the sururu fishery in Mundaú lagoon, Maceió-AL. Thirty nine fishermen were interviewed and also incursions were made for observations. Furthermore, sururus were collected to perform biometry. Residue of the sururu processing was collected to the fabrication of sururu waste meal (SWM), posteriorilly its bromatological composition was

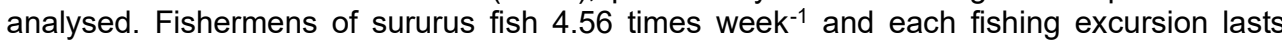
$5 \mathrm{~h} 26 \mathrm{~min}$, yielding 18.61 cans (18.61 to $37.22 \mathrm{~kg}$ soft tissue). Besides the sururus, $77.92 \%$ also catch fish, shrimp, and other organisms to complement the income. Average selling price was $\mathrm{R} \$ 6.92$ per $\mathrm{kg}$ of edible and CPUE from 3.42 to $6.85 \mathrm{~kg}$ edible day ${ }^{-1}$. The average size and weight are $33.21 \mathrm{~mm}$ and $1.62 \mathrm{~g}$, with $782.53 \mathrm{~g}$ of waste being generated to produce $1.0 \mathrm{~kg}$ of meat. SWM contained $37.00 \%$ calcium. It was verified that there is a need to create a management plan capable of reducing environmental impact in the lagoon, implement fishing programs and waste management, as well as improve the structure for the processing of that mollusc. Studies of the use of SWM as a source of calcium in diets are also recommended.
\end{abstract}

Keywords: Artisanal fishery. Bivalve mollusk. Fishing waste. Mussel gathering. Mussel shell.

\section{PESCA, PROCESSAMENTO, COMERCIALIZAÇÃO E PROPOSTA DE REUSO DE RESÍDUOS DA PESCA DO SURURU Mytella falcata NA LAGUNA MUNDAÚ, MACEIÓ - AL, BRASIL}

\begin{abstract}
RESUMO
Foi realizado um diagnóstico sobre a pesca, processamento, comercialização e geração de resíduos da pesca de sururu na laguna Mundaú, Maceió-AL. Trinta e nove pescadores foram entrevistados e incursões realizadas para observações. Sururus foram coletados para realização da biometria. Resíduo do processamento de sururu foi coletado para fabricação da farinha de resíduo de sururu (SWM), posteriormente sua composição bromatológica foi analisada. Os pescadores de sururus pescam 4,56 vezes por semana e cada excursão de pesca dura $5 \mathrm{~h} 26 \mathrm{~min}$, produzindo 18,61 latas $(18,61$ a $37,22 \mathrm{~kg}$ de tecido mole). Além dos sururus, $77,92 \%$ também pescam peixes, camarões e outros organismos para complementarem a renda. O preço de venda foi $\mathrm{R} \$ 6,92 \mathrm{~kg}^{-1}$ de edível e a CPUE variou entre 3,42 e 6,85 kg edível dia-1 ${ }^{-1}$. Tamanho e peso médios foram 33,21 mm e 1,62 g, sendo gerados $782,53 \mathrm{~g}$ de resíduos para produzir $1,0 \mathrm{~kg}$ de carne. SWM continha $6,45 \%$ de proteína, $0,77 \%$ de gordura; $37,00 \%$ de cálcio e $0,03 \%$ de fósforo. Verificou-se a necessidade de criar um plano de manejo na laguna, da implementação de programas de manejo de resíduos, bem como melhoria da estrutura para o processamento e
\end{abstract}


comercialização. Recomendam-se estudos sobre o uso de SWM como fonte de cálcio em dietas.

Palavras-chave: Concha de molusco. Coleta de mexilhão. Molusco bivalve. Pesca artesanal. Resíduo da pesca.

\section{INTRODUCTION}

The Mundaú lagoon is one of the main estuarine areas of the state of Alagoas - Brazil, sheltering an enormous number of species that are used as food and have significant commercial interest. Fishes, such as carapeba (Eugerres brasilianus and Diapterus rhombeus), mullet (Mugil cephalus), common snook (Centropomus undecimalis), fat snook (Centropomus parallelus) and catfish (Cathorops spixii and Arius herzbergii); macrocrustaceans, such as shrimps (Penaeus schmitti, Penaeus subtilis and Macrobrachium acanthurus); crabs (Ucides cordatus and Cardisoma guanhumi); besides the molluscs, such as massunim (Anomalocardia brasiliana), giant false donax (Iphigenia brasiliana), stout razor clam (Tagelus plebeius), mangrove oyster (Crassostrea rhizophorae) and the sururu (Mytella falcata), a bivalve mollusk that stands out among the aforementioned organisms.

As demonstrated by Puyana et al. (2009), Mytilidae family bivalves are important fishing and aquaculture resources in many regions of the world. The mytilidae species of commercial interest that occur in Brazil are four: Mytella falcata and Mytella guyanensis, estuarines; Perna perna and Mytilus edulis platensis, oceanics. This last species occurs only on the coast of Rio Grande do Sul, while the others are found all over the Brazilian coast (PEREIRA et al. 2003). Sururu, sutinga and bacucu (PEREIRA et al. 2007; ARAÚJO et al. 2009) are the most common names of the estuarine mussel Mytella falcata which, according Costa and Nalesso (2002), is considered as a synonymy of $M$. charruana.

Santos et al. (2010) observed that molluscs are among the mangrove shellfish, the most commonly exploited in Brazil. According Tamano et al. (2015), despite Mundaú lagoon being a very diversified and rich environment of organisms used as food and a source of income, bivalve molluscs represent their main exploited fishing resource. Data from the Brazilian Ministry of Fisheries and Aquaculture (MPA 2013) confirm that sururu is the second most captured species in the country, with $2,133.3 \mathrm{t}$ caught per year, which accounts for $15.27 \%$ of total marine and estuarine mollusc fish caught. Tamano et al. (2015) concluded that in addition to contributing to the nutritional support of many families, this mollusc is also the main and/or only source of income for a considerable portion of fishermen in the studied lagoon.

Concentrated on the banks of this lagoon is a significant number of houses belonging to fisherman. It is in this location, called Vergel do Lago (a district), where the processing and commercialization of the molluscs takes place. By concentrating these two stages of fishing, this location also becomes the disposal area for most of the waste (shells) that pile up near the household waste collection containers. However, such residues are found throughout the central site and the entire Senator Rui Palmeira Avenue, in which the said district is located. This study was conducted to diagnose general aspects of fishing, processing and commercialization of sururu, aiming to determine the potential of fishing waste generation and propose alternative uses for the processing residues of this mollusc.

\section{METHODS}

The studies contained here were conducted in three locations. The sururu fishery data were collected at Senator Rui Palmeira Avenue, located on the banks of the Mundaú lagoon, in Maceió - Alagoas, Brazil. The biometry, the production of sururu waste meal (SWM) and its chemical analysis were carried out in the Laboratory of Enzymology and Bromatology of the Federal University of Alagoas. Data compilation and analysis were performed at the Laboratory of Aquaculture and Aquatic Environment of the Federal Institute of Education, Science and Technology of Alagoas.

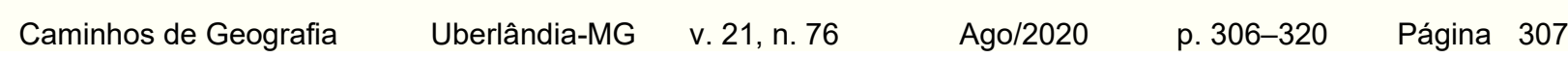


Fishing, processing, commercialization and a propose to fishery waste reuse of sururu Mytella falcata in the Mundaú Lagoon, Maceió - AL, Brazil
Luana Tieko Omena Tamano Beethoven Brandão Correia de Lima Joseane da Silva Daniel de Magalhães Araujo

The choice of the place to obtain information about sururu fishing was due to the fact that it is an urban area located only five kilometers from the city center of Maceió (Alagoas State Capital) and three kilometers from the municipal public market, where there is also the sale of sururu. In addition, this locality is situated near the banks of the Mundaú lagoon, with recognized tradition in the artisanal exploration of this shellfish. As already indicated, in Senator Rui Palmeira Avenue there is a large concentration of fishermen who fish for a diverse range of aquatic organisms, as well as habitations and tents used to process the mollusc and sell the edible part.

For the data collection, initially, there were incursions to the location in February 2012, with the objective of surveying the area and to identify possible leaders and fishermen of sururu. During the first visits to the location, a previously developed semistructured questionnaire was tested to consolidate the final version. After the necessary adjustments, the questionnaires were validated and the interviews started in February 2012 and were finalized in November of the same year. Thus, the analytical-descriptive research concerning the sururu fishery resulted from these interviews, which, besides the use of the semi-structured questionnaire, was based on free observation.

The variables were collected for the general characterization of the fishery (who taught the fishermen how to fish; if they had a canoe and a helper; if they were fishing other organisms besides the sururu; if there were accompanying fauna with the organisms that were fished; frequency of weekly fishing, duration (time) of each fishing excursion; and if the small sururus were returned to the environment). Environmental data from sururu fishing were characterized (existence of a prohibited fishing season in the sururu; if its quantity and size were the same as in the past; if there was an intensification of fishing of other organisms in the worst fishing periods for the sururu; if the diversity of species in the lagoon was the same as in the past; if there was influence of pollution in the fishing and commercialization of the sururus; and also if the fisherman had already witnessed excess mortality in the lagoon). In addition, information over the sururu processing waste generation was obtained (time spent on fishing until commercialization; place of sale; identification of the buyer; profit for each fishing excursion; use of shells in the community; and external interest in the purchase of shells).

The fishermen were approcahed directly, with formal presentation of the researchers and their institutional affiliation, description of the objectives of this research, as well as an explanation as to how the information would be used. Throughout the explanations, the researchers assured the fishermen that their answers would not be divulged individually, which would maintain their anonymity. Authorizations were requested for the interviews and the use of the information obtained.

It was found that it would be easier to approach fishermen during the processing or selling of sururu. When first approaching the fishermen, the researchers tried to use the snowball method (BAILEY, 1982). However, the fishermen preferred not to recommend specific colleagues in particular, choosing to randomly suggest other fishermen during the sururu processing. For this reason, the 39 interviews were conducted while the fishermen were processing the mollusc.

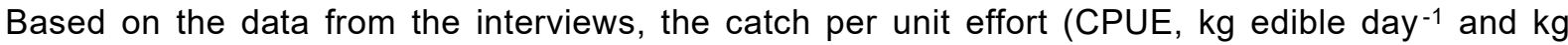
edible hour ${ }^{-1}$ ) were calculated for higher and lower meat yield for each 20 liter metal gallon containing live sururus (which are one or two kilograms of edible for each gallon of metal of 20 liters). The equation used for the two cases was:

\section{CPUE $=(A G \times M Y) / T$}

In which:

$A G=$ Average quantity of 20 liters-gallons containing sururus, that was 18,61 in this study; $M Y=$ Meat yield, in kilograms at 20 liters-gallons containing sururus; $T=$ Time (fishing day ${ }^{-1}$ or fishing hour $^{-1}$ ) to calculate CPUE. One day of fishing corresponded to 5.43 hours of activity in the present study.

The family income declared by the fishermen was compared to two other calculated family incomes. To calculate these other family incomes, the two meat yields mentioned above were considered. Thus, firstly, the average profit $(R \$)$ per fishing day was calculated, considering, for 
this, the average quantity of 20 liters of sururu, yield of meat in kilograms and the average declared price of sale per kilogram of meat. Both methodologies were applied in two meat yield scenarios described above. The first equation used to obtain the average profit per day of fishing can be seen below.

\section{APPD1 $=[(Q G \times M Y) \times P R]-(2 \times Q G)$}

In which:

APPD1 = Average profit in each fishery $\left(R \$\right.$ fishing day $\left.{ }^{-1}\right) ; Q G=$ Quantity of 20-liters gallon containing sururus; $M Y=$ Meat yield (kilogram for each 20 liter gallon containing sururus); $P R=$ Average sele price per kilogram of sururu meat, which was $R \$ 6.92 ; 2 \times Q G=$ Discount of $R \$ 2.00$ for each gallon of 20 liters containing sururu, once the fisherman pays this value to marisqueiras (mostly women, often children, responsible for performing the individual cleaning and separation of the sururus).

The second equation used to calculate the average profit per day of fishing is shown below.

\section{APPD2 = CPUE $\times 6.92$}

In which:

APPD2 $=$ Average profit in each fishery $\left(R \$\right.$ fishing day $\left.{ }^{-1}\right)$; $C P U E=$ catch per unit effort (sururu meat kilogram day $\left.{ }^{-1}\right) ; 6.92=$ Price $\left(R \$\right.$ sururu meat kilogram $\left.{ }^{-1}\right)$.

To obtain the average monthly income, APPD1 and APPD2 were multiplied by 18.26 , which corresponds to the average number of days that each fisherman fishes sururus per month (4.56 times per week $\times 4$ weeks per month).

\section{Sururu biometry, fabrication and bromatological composition of sururu waste meal (SWM)}

During the characterization period of fishermen and sururu fishery, recently collected molluscs were used to perform biometry. The soft tissues (edible) and percentages of shell in the live weight ratio were determined. With these data it was possible to calculate the amount of residues generated when a kilogram of sururu meat was produced. In addition, the SWM was made, which was analyzed in the laboratory to determine its nutritional composition, which allowed the investigation of the possibility of using it as a source of calcium in animal feeds.

To perform the biometry, live animals were collected directly from the fishermen and were taken to the laboratory for analysis. Digital analytical balance and digital paquimeter were used to weigh and measure 730 molluscs. In biometrics, the distance from the umbus to the ventral part of the shell (height), its length and the distance from the left valve to the right valve (width) were measured. After accurate measurements, the sururus were opened with bistoury and positioned open in a plastic box and carefully dried with absorbent paper. Each mussel was weighed whole, as well as its shells and soft tissues, to obtain the corresponding weights.

With the biometric data, the percentage values of the edible part and shells were used to calculate the amount (in grams) of residues (shells) generated when 1000 grams of sururu meat were produced. In the same way, the most recent fishery statistics on the sururu fishery in Alagoas (IBAMA, 2001a, 2001b, 2002, 2004, 2005, 2006, 2007, 2008 and 2009) and in Brazil (MPA, 2010, 2012 and 2013) were used to stipulate the production of sururu meat, generation of residues and amount of calcium generated in the sururu residue. The average price (Reais, $R \$$ ) of one kilogram of sururu meat was multiplied by the amount of sururu meat produced in Alagoas (2000 to 2009) and in Brazil (2007 to 2011), according to the publications cited above, to obtain the monetary values generated with this activity. These values were calculated according to the equations below:

Quantity of Sururu meat produced (Kilograms) $=$ Annual production (Alagoas or Brazil) $\times 56.10$ / 100

In which: $56.10 \%$ is the meat yield, obtained in the biometry test.

$\begin{array}{lllll}\text { Caminhos de Geografia } & \text { Uberlândia-MG } & \text { v. 21, n. } 76 & \text { Ago/2020 } & \text { p. 306-320 Página } 309\end{array}$


Quantity of Sururu waste (bark) generated (Kilograms) = Annual production (Alagoas or Brazil) $\times 43.90 / 100$

In which: $43.90 \%$ is the waste generated, obtained in the biometry test.

Quantity of calcium generated in sururu residue (shell) = Amount of sururu residues (shell) generated $\times 37.0 / 100$

In which: $37.00 \%$ is the composition of calcium in the sururu waste meal, analyzed in this study.

Negotiated values $($ Reais, $\mathbf{R} \$)=$ Sururu meat produced per year $\times 6.92$

In which: $\mathrm{R} \$ 6.92$ is the average price of one kilogram of sururu meat, declared by the fishermen interviewed, considering the direct sale to the consumer.

It is important to mention that there was no monetary correction of the values negotiated in the fishing activity of the sururu. The average selling price $(R \$ 6.92)$ was considered for the entire volume of fishing over the years. Thus, the price considered for one kilogram of sururu meat consists of direct sale to the consumer. However, they can be sold in the shells (locally called the sururu de capote) and through intermediaries, in both cases with lower prices. These variations may result in a drastic change in the calculated values for the commercialization of sururu, according to the proposed methodology of this study.

For the fabrication of SWM, the biometric test residue, composed almost entirely of shells, was used as well as the residue of soft tissue adhered to the shells. These residues were washed three times in running water to remove the impurities, immersed in sodium hypochlorite $(1.00 \%)$ for 24 hours, removed and dried in a recirculating oven (at 100 degrees Celsius for two hours) to remove chlorine residues. After drying, the shells were cracked, crushed in industrial blender and sieved (5 mm mesh). The powder collection was performed selectively, and the denser powder was crushed once more and sieved to homogeneous granulometry, here denominated SWM.

The bromatological analyzes of the SWM were performed according to Silva (2002), while calcium and phosphorus were determined by flame atomic absorption spectrophotometry, as recommended in the equipment manual (Cookbook Shimadzu 2002).

For the tabulation of the data and calculation of the average and percentages of answers obtained in the interviews, Excel (Microsoft 2000) was used. For the analysis of the data, the information reported by the fishermen in the interviews, as well as the informal reports and the interpretation of the researchers themselves were considered (Bruyne et al. 1977).

\section{RESULTS}

Table 1 presents the results referring to the general aspects of the sururu fishery in the Mundaú lagoon. Most fishermen (38.46\%) learned the profession from their parents, while $35.90 \%$ learned from other fishermen and $20.51 \%$ from other family members, but $5.13 \%$ said they learned on their own. Of the total fishermen interviewed, $69.23 \%$ owned the boat that was used to fish sururu, while $30.77 \%$ depended on the vessels of other fishermen to carry out their work.

Fishing was carried out with a helper by $48.65 \%$ of the fishermen, while $51.35 \%$ of them claimed to fish alone. According to the data collected, $22.92 \%$ of the interviewees were exclusively sururu fishermen. Among the remaining $77.08 \%$, in addition to the sururus, $35.42 \%$ fished fish, $22.92 \%$ fished shrimp and $18.75 \%$ fished other organisms. In the sururu fishing, $50.00 \%$ of the fishermen stated that there are by-catches while fishing for other organisms, and $56.00 \%$ declared that there was capture of species that were not directly target of the activity.

Fishermen fished 4.56 times per week and each fishing excursion lasted 05:26 minutes. For each day of fishing, they filled 18.6120 -liter cans with the whole sururus (still in the shells), which were taken for washing and processing. With regard to the return of small animals to the lagoon, 48, $65 \%$ declare doing so. 
Fishing, processing, commercialization and a propose to fishery waste reuse of sururu Mytella falcata in the Mundaú Lagoon, Maceió - AL, Brazil
Luana Tieko Omena Tamano Beethoven Brandão Correia de Lima Joseane da Silva Daniel de Magalhães Araujo

Table 1 - General aspects about the fishing of the sururu (Mytella falcata) in the lagoon Mundaú, Maceió - AL, Brazil ${ }^{1}$

VARIABLE

Studied Population

\begin{tabular}{|c|c|c|}
\hline & $\mathbf{n}$ & $\%$ \\
\hline \multicolumn{3}{|l|}{ Who did you learn to fish whit? } \\
\hline Parents & 15 & 38.46 \\
\hline Other family members & 8 & 20.51 \\
\hline Other fishermen & 14 & 35.90 \\
\hline By myself & 2 & 5.13 \\
\hline \multicolumn{3}{|l|}{ Do you have a canoe? } \\
\hline Yes & 27 & 69.23 \\
\hline No & 12 & 30.77 \\
\hline \multicolumn{3}{|l|}{ Do you have a fishing helper? } \\
\hline Yes & 18 & 48.65 \\
\hline No & 19 & 51.35 \\
\hline \multicolumn{3}{|l|}{ Except sururus, do you fish other organisms? } \\
\hline No other & 11 & 22.92 \\
\hline Other diverse organisms & 9 & 18.75 \\
\hline Fishe & 17 & 35.42 \\
\hline Shrimp & 11 & 22.92 \\
\hline \multicolumn{3}{|l|}{ Is there a secondary catch fauna for the sururu fishery? } \\
\hline Yes & 18 & 50.00 \\
\hline No & 18 & 50.00 \\
\hline \multicolumn{3}{|l|}{ Is there a secondary catch fauna for other organisms fished by you? } \\
\hline Yes & 14 & 56.00 \\
\hline No & 11 & 44.00 \\
\hline How many times do you fish weekly? & \multicolumn{2}{|c|}{4.56 (2 to 7 times) } \\
\hline How many hours do you fish daily? & \multicolumn{2}{|c|}{$5 \mathrm{~h} 26 \min (2$ to $12 \mathrm{~h})$} \\
\hline How many 20 -liters gallon containing sururus do you fish daily? ${ }^{2}$ & \multicolumn{2}{|c|}{$18.61(7$ to 45$)$} \\
\hline \multicolumn{3}{|l|}{ Do you return to the lagoon sururus with inappropriate size? } \\
\hline Yes & 18 & 48.65 \\
\hline No & 19 & 51.35 \\
\hline
\end{tabular}

1 Percentages were calculated according to the number of responses obtained for each question, which does not always represent the total number of interviewed fishermen $(n=39)$. 2 The reference to the 20 -liters gallon containing sururu occurs because fishermen use these gallons to measure the amount transported, to transport and to cook the molluscs.

Org.: of Authors, 2019.

Table 2 presents the results of a possible period of prohibition of sururu fishing, evolution of fishing volume, size of its catch and other organisms, information on the diversity of organisms fished, possible effects of pollution on fishing and commercialization and also in the mortality of organisms. Regarding a possible sururu fishing season, $88.89 \%$ of fishermen stated that there is no fishing prohibition period, while $11.11 \%$ said it exists. Comparing the present with the past, $32.43 \%$ of interviewees stated that the quantities of sururu fished were the same, while $43.44 \%$ assured that the amount was higher and $24.32 \%$ claimed that it was lower. Regarding the size of the sururu, $38.46 \%$ of the fishermen said the size of the sururu was equal; $5.13 \%$ of them said it was higher and $56.41 \%$ said it was lower. Regarding fishing volumes, $17.95 \%$ said that they was equal to the past, $43.59 \%$ higher and $38.46 \%$ lower. For $34.78 \%$ of the fishermen, the size of the fish was the same, while for $17.39 \%$ it was bigger and for $47.83 \%$ it was smaller. In the worst periods of sururu fishing, $19.44 \%$ of the fishermen increased their fishing effort, while $27.59 \%$ also did the same for fish and shrimp.

$\begin{array}{lllll}\text { Caminhos de Geografia } & \text { Uberlândia-MG } & \text { v. 21, n. 76 } & \text { Ago/2020 } & \text { p. 306-320 Página } 311\end{array}$ 
Fishing, processing, commercialization and a propose to fishery waste reuse of sururu Mytella falcata in the Mundaú Lagoon, Maceió - AL, Brazil
Luana Tieko Omena Tamano Beethoven Brandão Correia de Lima Joseane da Silva Daniel de Magalhães Araujo

Table 2 - Environmental aspects on the sururu (Mytella falcata) fishing in the Mundaú lagoon, Maceió $-\mathrm{AL}$, Brazil'1.

\section{VARIABLE}

\section{Studied Population}

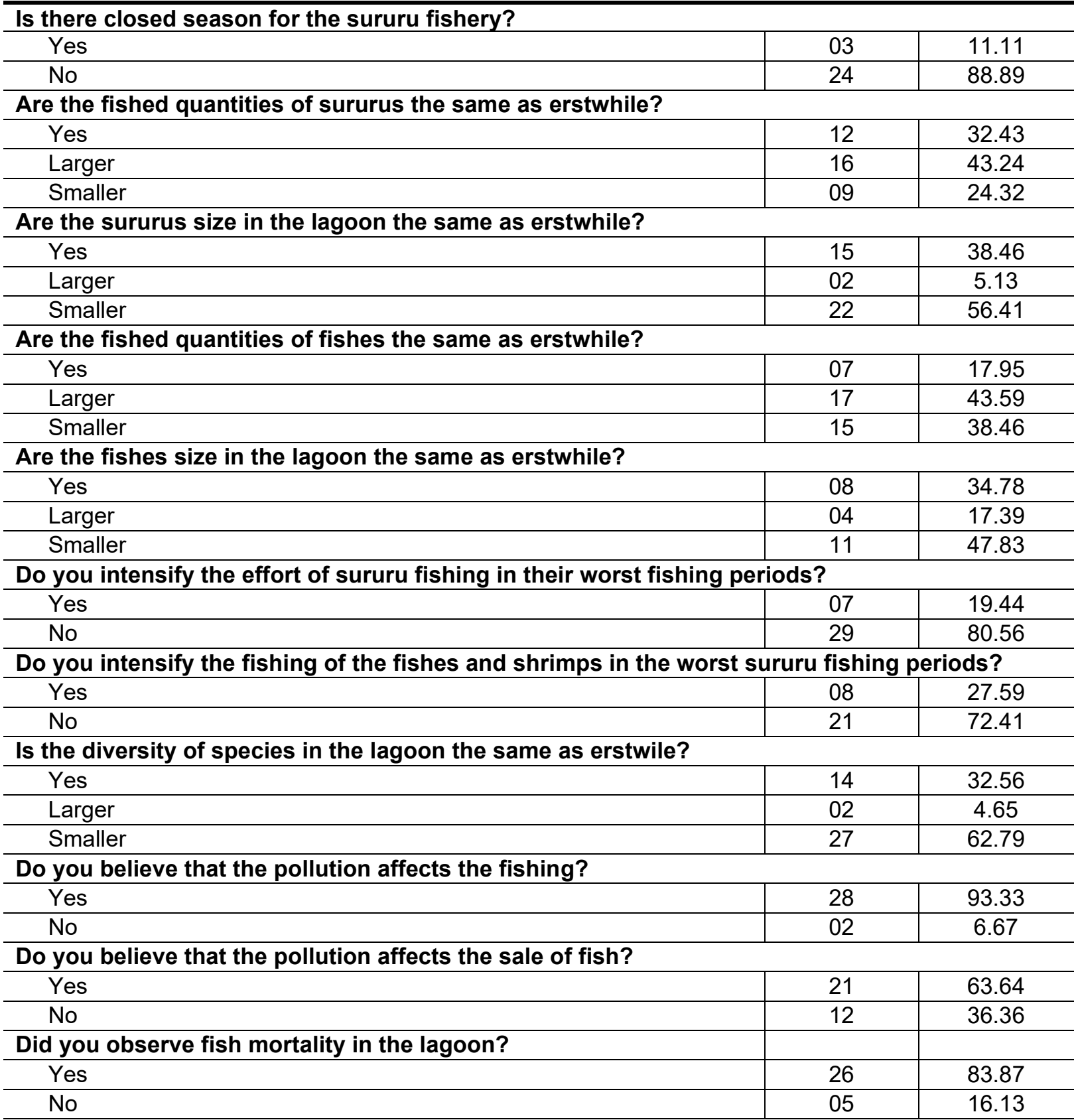

1 Percentages were calculated according to the number of responses obtained for each question, which does not always represent the total number of interviewed fishermen $(n=39)$.

Org.: of Authors, 2019.

Asked about a possible reduction in fish stocks, $32.56 \%$ of fishermen stated that the diversity of organisms was the same, $4.65 \%$ said it was larger, while $62.79 \%$ said it was smaller. For the vast majority, $93.33 \%$, pollution negatively affects fishing and, for $63.64 \%$, pollution affects commercialization. As a result of pollution, $83.87 \%$ of fishermen reported having seen fish mortality in the lagoon. 
Fishing, processing, commercialization and a propose to fishery waste reuse of sururu Mytella falcata in the Mundaú Lagoon, Maceió - AL, Brazil
Luana Tieko Omena Tamano Beethoven Brandão Correia de Lima Joseane da Silva Daniel de Magalhães Araujo

Table 3 presents data on the generation of residues in the processing and commercialization of sururu. On average, the time from the end of the fishing to the end of the processing of the mollusc was around $9 \mathrm{~h} 30 \mathrm{~min}$. Most fishermen, $89.74 \%$, sell it to intermediaries, $7.69 \%$ directly to consumers and $2.56 \%$ of them did not know who they were selling to. A large percentage of fishermen, $79.41 \%$, sell it on the edge of the lagoon, while $20.59 \%$ sell it elsewhere. According to the interviewees, on average, in each fishery, they earned $\mathrm{R} \$ 42.95$.

Table 3 - Aspects on sururu (Mytella falcata) waste generation and above sururu meat commercialization in the Mundaú lagoon, Maceió - AL, Brazil1

\begin{tabular}{|c|c|c|}
\hline \multirow{2}{*}{ VARIABLE } & \multicolumn{2}{|c|}{ Studied Population } \\
\hline & $\mathbf{n}$ & $\%$ \\
\hline After the fishing, how long does it take to sell the sururus? & \multicolumn{2}{|c|}{$9 \mathrm{~h} 30 \mathrm{~min}$} \\
\hline \multicolumn{3}{|l|}{ Where do you sell the sururus? } \\
\hline On the edge of the lagoon & 27 & 79.41 \\
\hline In other places & 07 & 20.59 \\
\hline \multicolumn{3}{|l|}{ For whom do you sell the sururus? } \\
\hline For intermediaries & 35 & 89.74 \\
\hline Direct to consumers & 03 & 7.69 \\
\hline I do not know to inform & 01 & 2.56 \\
\hline What is the average kilogram price of the sururu meat? & \multicolumn{2}{|c|}{$\mathrm{R} \$ 6.92$} \\
\hline How much is your average profit with each fishery? & $\mathrm{R} \$ 42$. & 5 to 150$)$ \\
\hline \multicolumn{3}{|c|}{ Sururu shells, wasted with the processing, are utilized in the community? } \\
\hline Yes & 01 & 2.63 \\
\hline No & 37 & 97.37 \\
\hline \multicolumn{3}{|c|}{ Was there any interest to buy or to collected sururu shells for some use? } \\
\hline Yes & 13 & 33.33 \\
\hline No & 26 & 66.67 \\
\hline
\end{tabular}

${ }^{1}$ Percentages were calculated according to the numbers of responses obtained for each question, which does not always represent the total number of interviewed fishermen $(n=39)$.

Org.: of Authors, 2019.

Asked if shells left over from mollusc processing were used in the community, $97.37 \%$ of fishermen responded negatively. For $66.67 \%$ of them, there were never people from outside the community interested in collecting or buying the shells, while $33.33 \%$ reported that there was interest.

Table 4 contains the sururu biometrics data. After tabulation of the data, the animals were classified into three size classes (height): less than $30 \mathrm{~mm}$; from $30 \mathrm{~mm}$ to $50 \mathrm{~mm}$ and more than $35 \mathrm{~mm}$. Thus, the respective mean height and weight for these three classes were $27.43 \mathrm{~mm}$ and $0.97 \mathrm{~g} ; 32.88 \mathrm{~mm}$ and $1.53 \mathrm{~g} ; 37.63 \mathrm{~mm}$ and $2.20 \mathrm{~g}$. Meat production was $54.39 \%$ for the minors, $56.38 \%$ for the media and $65.94 \%$ for the larger animals. The mean meat yield for the three categories analyzed was $56.10 \%$ of the total weight of the animal. 
Fishing, processing, commercialization and a propose to fishery waste reuse of sururu Mytella falcata in the Mundaú Lagoon, Maceió - AL, Brazil
Luana Tieko Omena Tamano Beethoven Brandão Correia de Lima Joseane da Silva Daniel de Magalhães Araujo

Table 4 - Sururus (Mytella falcata) biometry and potential to waste generation (shells) in the Mundaú lagoon, Maceió - AL, Brazil

\begin{tabular}{lrrrr}
\hline Size Class & Less than $\mathbf{3 0 \mathbf { m m }}$ & $\begin{array}{c}\text { Greater than 30 } \\
\text { Less than } \mathbf{3 5 \mathbf { m m }}\end{array}$ & $\begin{array}{c}\text { Greater than } \\
\text { 35mm }\end{array}$ & Mean \\
\hline Animals (\%) & 22,48 & 44,41 & 33,11 & 100,00 \\
Height (mm) & 27,43 & 32,88 & 37,63 & 33,21 \\
Lenght (mm) & 11,64 & 13,78 & 15,37 & 13,82 \\
Widht (mm) & 8,18 & 9,71 & 11,14 & 9,84 \\
Total weight (g) & 0,97 & 1,53 & 2,20 & 1,62 \\
Edible weight (g) & 0,43 & 0,66 & 0,94 & 0,70 \\
Shells weight (g) & 0,54 & 0,87 & 1,26 & 0,92 \\
Edible (\%) & 54,39 & 56,38 & 56,94 & 56,10 \\
Shells (\%) & 45,61 & 43,62 & 43,06 & 43,90 \\
\hline
\end{tabular}

${ }^{1}$ Data from 734 animals studied were separated into three size classes to allow a better analysis of the meat yield relative to the different sizes.

Org.: of Authors, 2019.

Table 5 shows the estimated quantities of sururu meat, residues (shell) and calcium generated, as well as the values negotiated with the sururu commercialization in Alagoas and Brazil. Considering the total period from 2000 to 2009 in Alagoas, 2,026,270 kg of sururu were exploited, resulting in 1,136,737 kg of meat, $889,532 \mathrm{~kg}$ of residues (shell), $329,127 \mathrm{~kg}$ of calcium in the shells and $R \$ 7,866,223$ in negotiated values with commercialization. In Brazil, considering the total period from 2007 to 2011, $9,814,000 \mathrm{~kg}$ of sururus were exploited, resulting in $5,505,654 \mathrm{~kg}$ of meat, $4,308,346 \mathrm{~kg}$ of shells (residues), $1,594,088 \mathrm{~kg}$ of calcium in shells and $\mathrm{R} \$ 38,099,125.00$ in negotiated amounts.

Table 5 - Production of sururus (Mytella falcata) and estimates of the production of meat, waste (shells), calcium in the waste and the values negotiated with the commercialization of this organism in Alagoas and in Brazil

\begin{tabular}{|c|c|c|c|c|c|}
\hline Year & \multirow{2}{*}{$\begin{array}{l}\text { Production of } \\
\text { Sururus }(\mathbf{K g})^{1}\end{array}$} & \multirow{2}{*}{$\begin{array}{l}\text { Sururu Meat } \\
(\mathbf{K g})^{3}\end{array}$} & \multirow{2}{*}{ Waste $(\mathrm{Kg})^{4}$} & \multirow{2}{*}{ Calcium $(\mathbf{K g})^{5}$} & \multirow{2}{*}{$\begin{array}{c}\text { Negociated } \\
\text { Values }(R \$)^{6}\end{array}$} \\
\hline Alagoas & & & & & \\
\hline 2000 & 171,200 & 96,043 & 75,156 & 27,808 & 664,619 \\
\hline 2001 & 217,900 & 122,241 & 95,658 & 35,393 & 845,914 \\
\hline 2002 & 161,400 & 90,545 & 70,854 & 26,216 & 626,574 \\
\hline 2003 & 134,700 & 75,566 & 59,133 & 21,879 & 522,922 \\
\hline 2004 & 137,800 & 77.305 & 60,494 & 22,382 & 534,956 \\
\hline 2005 & 172,560 & 96,806 & 75,753 & 28,028 & 669,899 \\
\hline 2006 & 217,930 & 122,258 & 95,671 & 35,398 & 846,030 \\
\hline 2007 & 276,670 & 155,211 & 121,458 & 44,939 & $1,074,066$ \\
\hline 2008 & 167,790 & 94,130 & 73,659 & 27,254 & 651,381 \\
\hline 2009 & 368,320 & 206,627 & 161,692 & 59,826 & $1,429,862$ \\
\hline TOTAL & $2,026,270$ & $1,136,737$ & 889,532 & 329,127 & $7,866,223$ \\
\hline Year & \multirow{2}{*}{$\begin{array}{l}\text { Production of } \\
\text { Sururus }(\mathbf{K g})^{1}\end{array}$} & \multirow{2}{*}{$\begin{array}{l}\text { Sururu Meat } \\
(\mathrm{Kg})^{3}\end{array}$} & \multirow{2}{*}{ Waste $(\mathrm{Kg})^{4}$} & \multirow{2}{*}{ Calcium $(\mathrm{Kg})^{5}$} & \multirow{2}{*}{$\begin{array}{l}\text { Negociated } \\
\text { Values }(R \$)^{6}\end{array}$} \\
\hline Brazil & & & & & \\
\hline 2007 & $1,298,000$ & 728,178 & 569,822 & 210,834 & $5,038,991$ \\
\hline 2008 & $2,029,000$ & $1,138,269$ & 890,731 & 329,570 & $7,876,821$ \\
\hline 2009 & $2,238,000$ & $1,255,518$ & 982,482 & 363,518 & $8,688,184$ \\
\hline 2010 & $2,116,000$ & $1,187,076$ & 928,924 & 343,701 & $8,214,565$ \\
\hline 2011 & $2,133,000$ & $1,196,613$ & 936,387 & 346,463 & $8,280,561$ \\
\hline TOTAL & $9,814,000$ & $5,505,654$ & $4,308,346$ & $1,594,088$ & $38,099,125$ \\
\hline \multicolumn{6}{|c|}{ 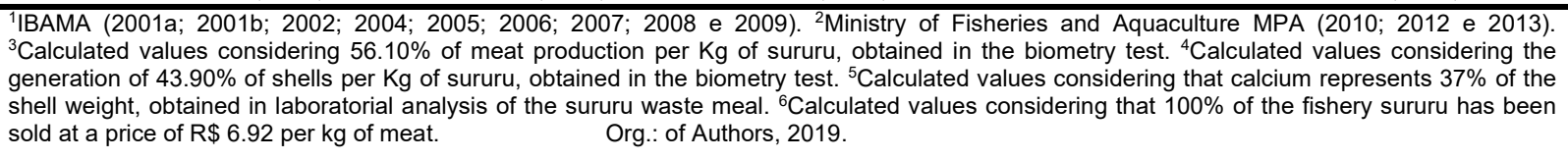 } \\
\hline aminhos d & Jeografia & ândia-MG & 76 & p. 306- & Página 314 \\
\hline
\end{tabular}


Fishing, processing, commercialization and a propose to fishery waste reuse of sururu Mytella falcata in the Mundaú Lagoon, Maceió - AL, Brazil
Luana Tieko Omena Tamano Beethoven Brandão Correia de Lima Joseane da Silva Daniel de Magalhães Araujo

Table 6 lists the values of the nutritional composition of the SWM. This meal had less than $1.00 \%$ dry matter in its composition and contained $6.45 \%$ crude protein, $0.77 \%$ ethereal extract, $91.80 \%$ ash, $37.00 \%$ calcium and $0.31 \%$ phosphor.

Table 6 - Nutritional composition of sururu waste meal (SWM) fabricated in the present study

\begin{tabular}{lcccccc}
\hline Variable & DM & CP & EE & Ash & Ca & P \\
\hline \% & 99,19 & 6,45 & 0,77 & 91,80 & 37,00 & 0,31 \\
\hline
\end{tabular}

$\mathrm{DM}=$ dry matter; $\mathrm{CP}=$ crude protein; $\mathrm{EE}=$ ether extract; $\mathrm{Ca}=$ calcium; $\mathrm{P}=$ phosphorus.

Org.: of Authors, 2019.

\section{DISCUSSION}

Artisanal fishing is a traditional activity with a wide family involvement. Thus, in this type of activity, the learning of the profession of fisherman is transmitted mainly from generation to generation, as already reported by Silva et al. (2014). For Ramires et al. (2007), not only is the knowledge about fishing in particular, but the whole culture in general, is transmitted through everyday experiences, by the relationship between the members of the communities. Learning how to fish for sururu does not differ from other types of fishing, although some of the interviewees affirmed having learned the activity on their own, by observation of the other fishermen.

Although this fishing activity is also called catching and the sururu is a benthic animal, which means that they are buried in the muddy bottom of the occurrence areas, fishermen need vessels to reach the most distant areas of the border and also those of greater depth. In the exploitation of this organism, normally, fishing tools are not used by fishermen, nor any personal protective equipment (PPE). Canoes and row boats are thus the only resources used by fishermen in carrying out the activity, a fact that justifies the majority owning their own vessel. However, a share of more than $30 \%$ of them need to work in partnership since they do not own a vessel. As a result, almost half of the fishermen interviewed fish together with another fisherman, described in this study as a helper.

In the various communities of artisanal fishermen, in general, it can be stated that fish are the main organisms exploited, followed by shrimp, as can be seen in the work of Carneiro et al. (2008). In the present study, only people who declared themselves to be fishers of sururus were interviewed. Besides these mussels, they also fish for fish and shrimp, for example. The exploitation of different organisms is important both for the subsistence of this group of fishermen and to increase their income. While the marisqueiras perform individual cleaning and separation of the sururus (shell and edible part), fishermen who exploit other organisms use this time to fish them.

The comparison between the weekly fishing frequency and the time allocated to each fishery could not be made due to the absence of reports available in the literature. It is imperative to emphasize that, in addition to fishing time, there is time spent processing the sururu. The sum of these two activities composes the total daily working time of these fishermen.

The processing of the mollusc involves the cooking, the separation of the edible parts of the shells and the packaging and the sale of the product. This activity is usually carried out in conjunction with other fishermen and/or family members. In carrying out these tasks, they can devote more than six hours of work, according to reports. Nevertheless, the number of hours worked would exceed eight hours per day and could reach 12 hours per day of fishing. It is not uncommon, according to the fishermen's own report, to carry out up to two fisheries per day, which would increase the number of hours of work effort, as can be found in Tamano et al. (2015).

As described in the results, 18.61 gallons of 18 liters were filled with live sururus in each fishery, these being washed and processed. The 18 liter containers used were originally used for paint, kerosene, margarine or oil, for example, and were reused as "pans" for the cooking of the mollusc. For a selection of banks (which are the deep parts of the lagoon where there is a big number of fixed organisms) where the fishery is realized, the fishermen considered, besides the quantity, the size of the animals. Banks with smaller and/or growing sururus cannot be explored. However, when caught, 
Fishing, processing, commercialization and a propose to fishery waste reuse of sururu Mytella falcata in the Mundaú Lagoon, Maceió - AL, Brazil
Luana Tieko Omena Tamano Beethoven Brandão Correia de Lima Joseane da Silva Daniel de Magalhães Araujo

they were not always returned to the lagoon. The return, when it happened, occurred during fishing, when fishermen realized that the animals were not in the proper size range.

Although it is the main organism explored in the Mundaú lagoon (COSTA and NALESSO 2002), with many families conducting commercial exploration throughout the year and there being seasonality in reproduction, there is no specific period for prohibition of sururu fishing. When questioned about the closed season (a period when fishing is banned), many fishermen said that they are aware of its importance. In this sense, Pereira et al. (2003) studied natural banks of two species of sururu and affirmed that there was no law from environmental agencies that recommended the minimum size for extraction of the natural banks of these Mytilidae.

Some fishermen were aware that the total volume of fishing increased exponentially due to the sum of the number of fishers and the frequency of commercial fishing. For them, the volume of fishing per person should be reduced because the number of sururus in proper size is no longer the same compared to the past, resulting in fishing for smaller sururus. However, "the more sururus we catch, the more we have" is a common report. This perception can be derived from the fact that, according to Pereira et al. (2003), the life cycle of the sururu is short (around 12 months). Thus, there is an indication that the withdrawal of animals increases the physical space at the bottom of the lagoon for a rapid recomposition of the natural stocks, possible through the accelerated life cycle. With regard to fish, fishermen reported that they were smaller than in the past, and claimed to know that there was a reduction in fish diversity. Faced with this, a portion of the fishermen claimed that they eventually increased the fishing effort of sururus, fish and shrimp, in an attempt to obtain or maintain a minimum remuneration. In this sense, Tamano et al. (2015) stated that the reduction in the quantity of fish in the Mundaú lagoon resulted in a greater fishing effort, directly impacting on fisher health issues.

For $93.33 \%$ of fishermen interviewed, the pollution of the lagoon affected the fishing and the commercialization of the sururu, with mortality reports from several groups of aquatic organisms. This perception of fishermen was equally reported by Santos and Sampaio (2013) when studying fishing in the same lagoon. The degradation of this estuarine environment is a problem already studied by Silva and Sousa (2008), who proposed the adoption of sustainable management of the Mundaú lagoon after detecting several negative impacts on the environment, such as siltation, landscape anthropization, water pollution, deforestation, erosion and biodiversity decline.

Sururu processing requires hard work over a long period of time. For this reason, the time spent between fishing and commercialization is equally long. When finalizing the fishing, while still in the vessel, the fisherman start the initial washing of the sururus. The water of the lagoon is placed inside the canoe and, with their legs, the fishermen press and push the muddy mass in which the organisms are inserted, removing it. This process is repeated several times. When they dock the vessel, they fill plastic boxes with the sururus and continue washing them. After this washing, the molluscs are delivered to the marisqueiras, who promote a more precise cleaning and separate the organisms individually, breaking the bissos that unite them. After separation, they are returned to the fisherman who starts the cooking process, which is done as follows: the 18 liter gallons, also used as "pans", are placed in campfires for cooking. In this procedure, the animals are slaughtered and their valves are opened, promoting detachment of the soft parts of the shells. After cooking, they are placed on wooden tables or on cement counters or tiles to be sifted. There is finally the separation of the meat, which is bagged in plastic packaging and put up for sale. The fishermen themselves are responsible for processing and selling the mollusc. Commercialization usually occurs on the banks of the lagoon and in the Municipal Public Market or other places by intermediaries, including in other Brazilian states, such as Pernambuco and Bahia. Due to the impossibility of storage in freezers, which many do not have, they end up delivering all the surplus fish to the intermediaries at prices much lower than those asked in direct sales to the consumer.

As described by fishermen, each18-gallon canister containing sururu can result in one to two kilograms of meat depending on the period of year and the size of the animals. Therefore, in a fishery, the amount of end product may vary from 18.61 to $37.22 \mathrm{~kg}$. CPUE ranged from 3.42 to $6.85 \mathrm{~kg}$ of meat per day (or 0.63 to $1.26 \mathrm{~kg} \mathrm{hour}^{-1}$ ), at 1.0 or $2.0 \mathrm{~kg}$ of edible part yield per 18 liters of gallons full of live sururus (in the shell). 
Fishing, processing, commercialization and a propose to fishery waste reuse of sururu Mytella falcata in the Mundaú Lagoon, Maceió - AL, Brazil
Luana Tieko Omena Tamano Beethoven Brandão Correia de Lima Joseane da Silva Daniel de Magalhães Araujo

Alves et al. (2015) carried out an ethnomapping of the natural banks of sururus in the Brazilian state of Sergipe and affirmed in their study that the variation of the fishing production can derive from the physical state of the animals, which can be "fatter" or "leaner", which can influence fishing effort. In the analysis, they also reported that fishermen can fish up to eight cans of 18 liters per day and that each can can results in 1.0 or $2.0 \mathrm{~kg}$, with the price ranging between $R \$ 6.0$ and $R \$ 10.00$, when delivered to the intermediary or directly to the final consumer. Freitas et al. (2012) studied the traditional knowledge of marisqueiras in the Brazilian state of Piaui and identified that the sururus are the most demanded molluscs in the region, with sales prices varying from $R \$ 7.0$ to $R \$ 10.0$ in 2010 , depending on the period of the year. No value of sururus CPUEs was found in the literature, so better comparison, discussion and understanding were not possible. However, Freitas et al. (2012) stated that, among the molluscs studied in loco, a greater effort for collection of the sururu is necessary.

Fishermen affirm they make a profit of $\mathrm{R} \$ 42.95$ on each fishery. However, in the two methodologies developed, both based on the information provided by the fishermen, the values diverge. The average yields of the fishery (APPD1, $R \$$ day $^{-1}$ fishing) calculated were $R \$ 91.56$ or $R \$ 220.34$ for the two different yields of edible parts. Using the second methodology (APPD2, R $\$$ day $^{-1}$ fishing), productivity values per fishery were $R \$ 23.71$ and $R \$ 47.43$, which are more in accordance with the direct reports of the fishermen. For the average monthly income, the estimated value was $\mathrm{R} \$ 784.27$. Nevertheless, when considering the smallest and highest CPUEs, the average monthly income estimated ranges from $R \$ 432.98$ to $R \$ 865.96$. In the work of Araujo et al. (2009), the average monthly income of sururu fishermen was presented as $R \$$ 235.00. Tamano et al. (2015), based on direct reports from fishermen, stated that the average monthly income of $97.44 \%$ of the fishermen of this organization was a Brazilian minimum wage $(R \$ 622.00$ in 2012).

With regard to the different values declared as monthly family income of fishermen, it is necessary to consider, besides the reference year for data collection, several other factors. Fishing for these organisms is not always the only family income, since many family members have carried out other work, as pointed out by Tamano et al. (2015). In addition, it is necessary to analyze how many of the total sururus caught are sold with or without shells, whether the sale occurs directly to the final consumers or to the intermediaries, and where the point of sale is located, which in the present study is in the state's capital.

Based on the interviewees' claims, it is known that there is practically no use for the shells, and only its use in pots for plants is reported. As stated above, it is common to find the shells of the animals along Senator Rui Palmeira Avenue. Since inadequate disposal is an old problem, there are concerns of governmental entities, as well as studies that aim to give a more environmentally appropriate destination to shells. These shells were studied as components of anaerobic reactors capable of stabilizing the $\mathrm{pH}$ and, consequently, promoting the biodigestion of residues from the artisanal production of cassava flour (SILVA et al., 2013); as well as in the construction, with the incorporation of shell powder into concrete blocks (MARINHO et al., 2016).

There are few studies in which the biometric data of sururus can be obtained. Araújo et al. (2009) studied the management of the sururu fishery in the state of Sergipe, obtaining an average length of $29.40 \mathrm{~mm}$ and an average weight of $2.14 \mathrm{~g}$, and stated that it would take $800( \pm 85)$ sururus to produce one kilogram of edible parts. In other words, the weight of the edible part of each animal would be approximately $1.25 \mathrm{~g}$. Pereira et al. (2003) analyzed the estimated production of two species of sururus in several natural banks in the state of São Paulo and observed that the maximum length of the animals was 65 and $46 \mathrm{~mm}$; while the mean weights ranged from 2.85 to $4.01 \mathrm{~g}$ and from 0.10 to $1.79 \mathrm{~g}$, respectively, for Mytella guyanensis and Mytella falcata. These authors also stated that the commercial size of M. falcata would be $30 \mathrm{~mm}$, because Mytilidae, with smaller size than these, present low yield of meat.

The mean weight of one sururu in the present study was $1.62 \mathrm{~g}$, while the mean weight of the soft parts was $0.70 \mathrm{~g}$. Therefore, approximately 1,429 animals would be needed to produce one kilogram of edible parts. Considering that the average weight of one sururu is composed of $56.10 \%$ of soft part and $43.90 \%$ of shell, it is possible to calculate that the production of one kilogram of edible parts produces $782.53 \mathrm{~g}$ of residue. In this study, the minimum and maximum sizes of the animals were 10.38 and $47.59 \mathrm{~mm} .77 .52 \%$ 
Fishing, processing, commercialization and a propose to fishery waste reuse of sururu Mytella falcata in the Mundaú Lagoon, Maceió - AL, Brazil
Luana Tieko Omena Tamano Beethoven Brandão Correia de Lima Joseane da Silva Daniel de Magalhães Araujo

of them with at least $30 \mathrm{~mm}$, size were considered commercially viable by Pereira et al. (2003), and it was also possible to identify higher meat yield in larger animals.

The data presented in Table 5 demonstrate the importance of the organism for fishing in the lagoons of the State of Alagoas and Brazil in general as a source of food and income, highlighting the potential for the generation of shells that can be used for other activities, as will be discussed below. According to MAPA (2013) among molluscs, the mussel Perna perna appears as the most caught species in Brazil in 2011, with $3,772.50 \mathrm{t}$, which represented approximately $27.00 \%$ of the total of this category. The sururu is the second with $2,133.30 \mathrm{t}$, or $15.27 \%$ of the total. The latest official data on Brazilian fisheries in which the sururu is quoted are not available. In consequence of the lack of similar research available, a better discussion on the generation of edible parts and the generation of waste is not possible.

Shells of bivalve molluscs are composed mainly of minerals, mainly calcium. Nevertheless, the contained crude protein is derived from soft parts left over during biometry, as well as from barnacles that are commonly embedded in shells and have not been removed. In the processing performed by the fishermen, unlike the one performed in the biometrics, the meat was separated after cooking, which stiffened the soft parts, followed by sieving, which facilitated the separation. The processing done by the fishermen should drastically reduce the percentage of proteins in the residue.

With regard to SWM, it contained calcium levels $(37.00 \%)$ slightly higher than those determined by Silva et al. (2010) for shells of Crassostrea gigas and Perna perna, which varied between 33.00 and $34.80 \%$, and similar to those presented by Rostagno et al. (2005) for limestone (38.40\%), the main source of traditional calcium in non-ruminant animal diets. The use of waste from the processing of aquatic organisms from fisheries or aquaculture has increased due to environmental and economic issues. Thus, Naylor et al. (2009) stated that the use of seafood processing residues in feeding aquatic organisms also occurs due to the scarcity of other protein sources. For these authors, a new ingredient should present nutritional adequacy, immediate availability, ease of handling, transport and storage. According to them, the use of the ingredient should be based on the health and zootechnical performance of the fish, but should also promote less pollution and stress to the ecosystem and be competitively priced.

Although the studies presented here are initial, it is possible to affirm that SWM has some qualities for use as feed ingredient, such as immediate availability, ease of handling, processing, transport and storage. Furthermore, it has high calcium content, can provide reduction of environmental problems and appears to be economically viable. With regard to the zootechnical, economic and animal health performance issues, it is recommended to carry out calcium bioavailability studies in digestibility tests and tests of zootechnical performance for the species in order to allow a better analysis of the use of this meal shells as an ingredient in food.

\section{FINAL CONSIDERATIONS}

Through the interviews provided by the fishermen, together with the in loco observations and the analyses carried out, it is possible to affirm the evident need to implement plans of environmental and fishing management of the sururu in the Mundaú lagoon. Biometrics confirm that the processing of larger sururus results in higher meat yield and reduction of waste production. The residue meal from the sururu processing produced in this study has a calcium content (37.00\%) similar to limestone, and its potential use as a source of this mineral in aquaculture (and other animal species) rations should be better studied. This use is highlighted as a way to reduce the polluting potential resulting from the inappropriate disposal of shells, as well as allowing the production of a new ingredient for animal feed and income generation for fishermen.

\section{ACNOWLEDGMENT}

The first author would like to thank to the Brazilian National Council for Scientific and Technological Development (CNPQ) for the PhD fellowship. The second and third (Scientific Initiation) authors as well as the last author (Research Productivity Scholarship) wish to thank Federal Institute of Education, Science and Technology of Alagoas (IFAL) for the fellowships granted. 


\section{REFERENCES}

ARAÚJO, A.R.R.; SILVA, F.D.; SANTANA, R.F.; LOPES, F.C. 2009 Gestão da pesca de Mytella charruana (D' Orbigny, 1846) no litoral do estado de Sergipe: indicadores de sustentabilidade. Revista Brasileira de Engenharia de Pesca, v. 4, p. 56-70, 2009.

ALVES, A.C.; MELO, F.P.M.; SOUZA, R.M. Etnomapeamento dos bancos naturais de sutinga (Mytella charruana) no estuário do Rio Cajaíba-SE. In: MELO E SOUZA, R.; SANTOS, S. S. C.; SANTOS, E. A. Vivências e práticas socioambientais: metodologias aplicadas em comunidades. GEOPLAN/CNPQ/UFS, São Cristóvão. 2015, 200 p.

CARNEIRO, M.A.B.; FARRAPEIRA, C.M.R.; SILVA, K.M.E. O manguezal na visão etnoecológica dos pescadores artesanais do Canal de Santa Cruz, Itapissuma, Pernambuco, Brasil. Biotemas, v. 21, p. 147155, 2008. https://doi.org/10.5007/2175-7925.2008v21n4p147

COOKBOOK SHIMADZU. Operation manual: atomic absorption spectrophotometer AA 6800. Osaka: 2002. 157p.

COSTA, K.G. e NALESSO, R.C. Cultivo experimental de Mytella falcata (Orbigny, 1846) e M. guyanensis (Lamarck, 1819), no estuário do Rio Piraquê-açu (Aracruz, ES). Acta Limnologica Brasiliensia, v. 14, p. 15-22, 2002.

BAILEY, K.D. Methods of Social Research. New York: The Free Press, 1982. 553p.

BRUYNE, P.; HERMAN, J.; SCHOUTHEETE, M. Dinâmica da pesquisa em ciências sociais: os pólos da prática metodológica. Rio de Janeiro: F. Alves Editora, 1977. $251 \mathrm{p}$.

FREITAS, S.T.; PAMPLIN, P.A.Z.; LEGAT, J.; FOGAÇA, F.H.S.; BARROS, R.F.M. Conhecimento tradicional das marisqueiras de Barra Grande, área de proteção ambiental do delta do Rio Parnaíba, Piauí, Brasil. Ambiente \& Sociedade, v. 15, p. 91-112, 2012. https://doi.org/10.1590/S1414$\underline{753 \times 2012000200006}$

INSTITUTO BRASILEIRO DO MEIO AMBIENTE E DOS RECURSOS NATURAIS RENOVÁVEIS. IBAMA. Boletim estatístico da pesca marítima e estuarina do nordeste do Brasil 2000. Tamandaré: CEPENE. 2001a. 139 p.

Boletim estatístico da pesca marítima e estuarina do nordeste do Brasil 2001. Tamandaré: CEPENE. 2001b. 140 p.

Boletim estatístico da pesca marítima e estuarina do nordeste do Brasil 2002. Tamandaré: CEPENE. 2002. 209 p.

Boletim estatístico da pesca marítima e estuarina do nordeste do Brasil - 2003. Tamandaré: CEPENE. 2004. $198 \mathrm{p}$.

Boletim estatístico da pesca marítima e estuarina do nordeste do Brasil 2004. Tamandaré: CEPENE. 2005. $152 \mathrm{p}$.

Boletim estatístico da pesca marítima e estuarina do nordeste do Brasil 2005. Tamandaré: CEPENE. 2006. $217 \mathrm{p}$. 2007. 157p.

Boletim Estatístico da Pesca Marítima e Estuarina do Nordeste do Brasil 2006. Tamandaré. 2008a. 224p.

Boletim Estatístico da Pesca Marítima e Estuarina do Nordeste do Brasil 2007. Tamandaré 2008b. $113 \mathrm{p}$.

Estatística da Pesca 2008 - Brasil: grandes regiões e unidades da federação. Brasília: Ibama,

MARINHO, E.C.; NASCIMENTO, J.C.R.; SILVA, J.S.; ALMEIDA, T.G.S.; ALBUQUERQUE, T.H.S.; FONSECA, L.P. Incorporação de pó de conchas de sururu em formulações de blocos de concreto. Cadernos de Graduação - Ciências exatas e tecnológicas, v. 3, p. 139-150, 2016.

MINISTÉRIO DA PESCA E AQUICULTURA. MPA. Boletim estatístico da pesca e aquicultura 20082009. Brasília: MPA, 2010. 101 p.

Boletim estatístico da pesca e aquicultura 2010. Brasília: MPA, 2012. 128 p. 
Boletim estatístico da pesca e aquicultura 2011. Brasília: MPA, 2013. 60 p.

NAYLOR, R.L.; HARDY, R.W.; BUREAU, D.P.; CHIU, A.; ELLIOTT, M.; FARRELL, A.P.; FORSTER, I.; GATLIN, D.M.; GOLDBURG, R.J.; HUA, K.; NICHOLS, P.D. Feeding aquaculture in an era of finite resources. Proceedings of the National Academy of Sciences of the United States of America, v. 106, p. 15103-15110, 2009. https://doi.org/10.1073/pnas.0905235106

PEREIRA, O.M.; HILBERATH, R.C.; ANSARAH, P.R.A.C.; GALVÃO, M.S.N. Estimativa da produção de Mytella falcata e de M. guyanensis em bancos naturais do estuário de llha Comprida - SP - Brasil. Boletim do Instituto de Pesca, v. 29, p. 139 - 149, 2003. https://doi.org/10.14210/bjast.v11n1.p21-29

PEREIRA, O.M., GALVÃO, M.S.N.; PIMENTEL, C.M.; HENRIQUES, M.B.; MACHADO, I.C. Distribuição dos bancos naturais e estimativa de estoque do gênero Mytella no estuário de Cananéia, SP, Brasil. Brazilian Journal of Aquatic Science and Technology, v. 11, p. 21-29, 2007.

PUYANA, M.P. PRATO, J. DÍAZ, J.M. Mytella charruana (D'ORBIGNY) (MOLLUSKA: BIVALVIA: MYTILIDAE) em la Bahía de Cartagena, Colombia. Boletín de Investigaciones Marinas y Costeras INVEMAR, v. 41, p. 213-217, 2012.

RAMIRES, M.; MOLINA, S.M.G.; HANAZAKI, N. Etnoecologia caiçara: o conhecimento dos pescadores artesanais sobre aspectos ecológicos da pesca. Biotemas, v. 20, p. 101-113, 2007.

ROSTAGNO, H.S.; ALBINO, L.F.T.; DONZELE, J.L.; GOMES, P.C.; OLIVEIRA, R.F.; LOPES, D.C.; FERREIRA, A.S.; BARRETO, S.L.T.; EUCLIDES, R.F. Tabelas brasileiras para aves e suínos. Viçosa, MG: UFV, 186 p. 2005.

SANTOS, E.C. e SAMPAIO, C.L.S. A Pesca artesanal na comunidade de Fernão Velho, Maceió (Alagoas, Brasil): de tradicional a marginal. Revista da Gestão Costeira Integrada, v. 13, p. 513-524, 2013. https://doi.org/10.5894/rgci428

SANTOS, H.S.S.; BEASLEY, C.R.; TAGLIARO, C.H. Changes in population characteristics of Mytella falcata (d'Orbigny, 1846) beds, an exploited tropical estuarine mussel. Boletim do Instituto de Pesca, v. 36, p. 73-83, 2010.

SANTOS, M.A. A experiência vivida na Reserva extrativista Marinha Baía do Iguape/BA: Diálogo de saberes, planejamento, educação e autonomia. Caminhos de Geografia, v. 9, p. 1-16, 2008.

SILVA, C.O.; SILVA, A.O.; TIMOTEO, D.A.S.; SANTOS, M.B. Estudo do uso de conchas de sururu (Mytella falcata) no controle de pH da manipueira em reator anaeróbio UASB. Revista Ibero-Americana de Ciências Ambientais, v. 4, p. 111-118, 2013. https://doi.org/10.6008/ESS2179-6858.2013.002.0007

SILVA, D.; DEBACHER, N.A.; CASTILHOS JUNIOR, A.B.; ROHERS, F. Caracterização físico-química e microestrutural de conchas de moluscos bivalves provenientes de cultivos da região litorânea da ilha de Santa Catarina. Quím. Nova, v. 33, p. 1053-1058, 2010. https://doi.org/10.1590/S0100$\underline{40422010000500009}$

SILVA, D.F.; SOUSA, F.A.S. Proposta de manejo sustentável para o Complexo Estuarino-Lagunar Mundaú/Manguaba (AL). Revista Brasileira de Geografia Física, v. 1, p. 78-94, 2008. https://doi.org/10.26848/rbgf.v1i2.232611

SILVA, D.J. Análise de alimentos: métodos químicos e biológicos. 3. ed. Viçosa: UFV. 2002. 235p.

SILVA, E.F.; OLIVEIRA, J.E.; SCHIAVETTI, A. Conhecimento ecológico local (CEL) na pesca artesanal da Reserva de Desenvolvimento Sustentável Estadual Ponta do Tubarão - RN, Brasil. Boletim do Instituto de Pesca, v. 40, p. 355-375, 2014.

TAMANO, L.T.O.; ARAUJO, D.M.; LIMA, B.B.C.; SILVA, F.N.F.; SILVA, J. Socioeconomia e saúde dos pescadores de Mytella falcata da Lagoa Mundaú, Maceió-AL. Boletim do Museu Paraense Emílio Goeldi. Ciências Humanas, v. 10, p. 699-710, 2015. https://doi.org/10.1590/1981-81222015000300011

Recebido em: 10/01/2020

Aceito para publicação em: 03/07/2020 